\title{
「コフィン・テキスト」における「二柱のマアト」（M;cty）
}

\section{Dual Maat (Mæcty) in the Coffin Texts}

肥 後 時 尚 HIGO Tokihisa

\begin{abstract}
Maat ( $\left.m 3^{\circ} t\right)$ is an ancient Egyptian comprehensive concept connoting justice, truth, and fairness while focusing on the meaning of the order of the universe. This concept was deified as a goddess of justice or truth $\left(m_{3} ; t\right)$ and appeared in various texts throughout ancient Egyptian history. This article analyzes the portrayal of goddess Maat in the Coffin Texts, which are known as funerary texts during the Middle Kingdom. In addition to the Pyramid Texts from the Old Kingdom and the Book of the Dead from the New Kingdom, the Coffin Texts are some of the most important resources for understanding ancient Egyptian religion. The Coffin Texts contain over 1,000 spells and include more than 190 descriptions of Maat requiring further examination.

Furthermore, this article examines the eight expressions known as the Dual Maat (M;cty), written as the dual form of the goddess Maat. The reduplication of a deity who was usually represented in a single form is unique among ancient Egyptian deities. The results of the analysis reveal that the Dual Maat reflected three noticeable qualities of Maat: (1) the dual goddesses had a specific relationship with Sokar, the god of the netherworld (spells 479 and 660); (2) they were independent goddesses that empowered and stood by the deceased (spells 660, 149, and 416); and (3) they developed a unique relationship with Re, the sun god (spells 682 and 693).
\end{abstract}

キーワード：古代エジプト，マアト，コフィン・テキスト，エジプト宗教，二柱のマアト

\section{I.はじめに}

古代エジプトのマアト $(m ; t)$ は, 「世界の秩序」という意味を中心として正義や公正, 真実, 秩 序など多くの意味を併せ持つ包括的な概念である。この概念は，およそ三千年におよぶ古代エジプ トの歴史を通じて, 王権や思想, 文化に絶えず影響を与えた。王は国を統治し, 秩序を維持するた めの神的属性の一つとしてマアトを備え, また同時にマアト, すなわち秩序の維持は王の義務であっ た。一方でこの概念は, しばしば神格化され，神話にも現れる。さらに，マアトは，現世における 行為の善悪の判断基準として死後の世界にも登場する。膨大な資料に現れるマアトの概念は, 複数 の意味や側面を併せ持った。

このような重要性と特殊性から, マアトの概念は早くは19世紀から注目されてきた。ヴィーデマ ン（Wiedeman 1887）に始まるマアト研究は, その後ブリーカー（Bleeker 1929）やモレ (Moret 1940)，フランクフォート（Frankfort 1948），ウイルソン（Wilson 1954）をはじめとする多くの研

* 関西大学大学院文学研究科博士課程

Graduate Student, Graduate School of Letters, Kansai University

(C) The Society for Near Eastern Studies in Japan 
究者に引き継がれ, 基礎的な理解が確立された。近年では, リヒトハイム (Lichtheim 1992), ティー ター（Teeter 1997），カレンガ（Karenga 2004）によってマアトの持つ特定の側面に関する研究が なされ, 図像表現や文献資料に現れるマアトの詳細な分析が継続されている。しかし, 先行研究で 取り扱われた資料は，マアトに関連する数多くの資料の一部にすぎず，マアトの持つ性格について は未だ不明の点が多く，とりわけ葬祭文書に現れるマアトに注目した研究は，十分とは言い難い。 そこで, 本稿では, 従来のマアト研究において注目されてこなかった中王国時代の葬祭文書である 「コフィン・テキスト」に着目し，そこに見られる「二柱のマアト」(M;ty) と呼ばれる特殊な形態 の事例をとりあげ，これまで論じられてこなかったマアトの一側面を明らかにする。

古代エジプト人が想起した死後の世界や思想を如実に反映した文献資料群である葬祭文書は, 古 王国時代の「ピラミッド・テキスト」や中王国時代の「コフィン・テキスト」，そして新王国時代 以降に登場する「死者の書」に代表されるように, エジプトの各時代を通して使用された。それら はマアトへの言及も数多く含んでおり, 死後の世界におけるマアトの研究において最も重要な資料 であるといえる。しかし,「死者の書」に登場するマアトの特徴や役割がしばしばとりあげられる 一方で，その他の葬祭文書に記されたマアトへの注目は少ない。とりわけ，「コフィン・テキスト」 には筆者が確認する限りで190例を超えるマアトの記述が含まれており, 中王国時代の死後の世界 におけるマアトの一側面を探究するための最も有効な資料の一つだといえる。筆者は「コフィン・ テキスト」のマアトの事例を検討するなかで，「二柱のマアト」と呼ばれる特殊な表現を確認した。 本稿では, これまで注目が集められなかった「コフィン・テキスト」におけるマアト研究の一つと して，同資料に現れる「二柱のマアト」の事例をとりあげ，この特殊な一側面を考察する。

\section{II.「コフィン・テキスト」}

「コフィン・テキスト」は, 主として中王国時代の棺の内側に記された呪文の総称である。この 呪文集は, 他の葬祭文書と同様に, 故人が来世で復活するために必要とする呪文で構成されてお り, 神々への賛歌や死後の世界の描写, 変身の呪文や魔物を追い払うための呪文, 供物の呪文など からなる。この「コフィン・テキスト」の最大の特徽は, 「ピラミッド・テキスト」のように王族 にのみ使用されたのではなく, 有力な州候やその妻といった王族以外の人々にも使用された点にあ る。また, 呪文の種類が多いだけでなく, 棺の出土地によって呪文の種類や配列が異なるなどの地 域性が見受けられることも知られている。多くの呪文にテキストごとの多様性がある点も特徴の一 つであり, 中王国時代における古代エジプト人の思想を探るうえで, 最も重要な資料の一つに位置 づけられている。

膨大な資料に記された「コフィン・テキスト」は，1935年から 1961年にかけてデ・バックによっ て編纂された $(C T$ ：以下略号一覧参照 $)$ 。1 49 種類の資料から呪文を転写・配列した全 7 巻が出版 されると,「コフィン・テキスト」は, 他に例を見ない中王国時代の葬祭文書として多くの研究者 の関心を集めた。その後, 1992年にデ・バックの生誕 100 周年を記念して開催された国際会議The

（1）その他の代表的な研究には, Morenz 1973; Altenmüller 1975; Tobin 1989; Assmann 1990; Hornung 2005が挙 げられる。 
World of Coffin Textsでは, 文献学や考古学, 宗教学, そして言語学といった多様な視点に基づく「コ フィン・テキスト」とそれが記された木棺資料に関する近年の研究成果が公表された。

しかし, 呪文の内容に宗教的・神話的要素が多分に含まれていることから, テキストの理解は極 めて困難であり，「コフィン・テキスト」の研究は今なおその途上にある。ウィレム（H. Willem） の言葉を借りれば,「エジプト学研究者は, 依然としてそれらの理解に達するための始まりにいる」 (Willems 1996, v)のであり, 今後の更なる研究の進展が望まれる。マアト研究においても同様に,「コ フィン・テキスト」のなかに190例に及ぶマアトの記述が確認される一方で, これらの事例に注目 した研究はこれまで十分になされていない。したがって，「コフィン・テキスト」の翻訳と解釈を 踏まえ, 各呪文に登場するマアトの記述を読み解くことは, 中王国時代におけるマアトの特徵や意 義をより具体的に理解する一助となりうる。

\section{III. コフィン・テキストにおけるマアトのー側面}

\section{1. ニ柱のマアト $(M ;$ ety $)$}

「二柱のマアト」(Mzty) と明確に記述されたマアトの表現は,「コフィン・テキスト」の7種類 の呪文から 8 例確認できる。マアト $(M ; t)$ の双数形である M ctyは, この語の多くに用いられる決 定詞触が示す通り，通常は二柱のマアト女神を意味するが，おびただしい数の古代エジプトの神々 のなかで, 本来一柱である神が二柱の神として表現される例は極めて少ない。さらに，この二柱の 女神が宗教上, 重要な位置にあったことは,「死者の書」における最も重要な死者の裁判の場面に おいて，Mrtyの語が「二柱のマアトの間」（wsht M ‘ty）と呼ばれる裁判の場の名称に用いられてい ることにより示される。

以下, Mrtyの記述を含む 7 種類の呪文に注目し, そこに見られる「二柱のマアト」の特徵を考察 する。呪文については, フォークナー（Faulkner 1973-78), バルゲ（Barguet 1986), カリエ (Carrier 2004）の研究を参照しつつ, 蓋然性の高い翻訳と解釈を提示する。なお, 呪文の番号と表記はデ・バッ クの集成にしたがい，象形文字の転字にあたって補完されるべき文字を［］，欠如した音を（） で補足した。各呪文のMrctyの事例には事例番号（i-viii）と傍線を付す。

\section{2. 下界の神ソカル $(S k r)$ との関係}

（事例 i）呪文第479章 $C T$ 6, 41r-42e, [P. Gard. 2]

41 [r] m;3 wi whew rmt

[s] $\quad d g(i) n . i$ whew ntrw

[t] $\quad n$ hff.tn wi $n$ зmm. th wi

（２）呪文第1033番の資料B1C，B3L上にも，M3tyの記述が確認されたが，B1Cを除く他の 13 点の資料上では $n b$ $m_{3} s$ で表記されており, 文意的にも「二柱のマアト」の意味となり得ないため, 誤記と判断し, 本稿では割愛した $(C T$ 7,268)。

（３）その他の双数形で表される神としては，RhwyやRwty，Drtyなどが挙げられるが，いずれの神も本来の一柱神

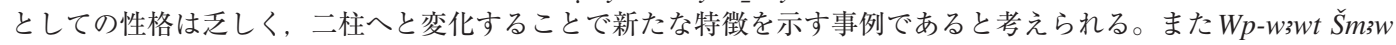
やWp-wzwt Mhwのように明らかにエジプトの二元性との関連を示す人格神の組み合わせも存在するが, マアトの 双数形の内容が特定されうる事例はこれまで確認されていない。 
[u] $\quad n \operatorname{ir}(i) . t n m r t . \underline{t} n$ r.i

[v] n-ntt pr(i).n.ỉ is m ỉb.s

[a] snšnš.n.ì hrddt.s m Skrn (i)Mzcty

[b] wnm.ìr [.ỉ]fgn.ỉ $m$ ert.i

[c] m;3 wint $(y) w$

[d] $d w ;[w] \operatorname{liwt}(y) w$

[e] din.int $(y) w$ im i’

私を見よ！おお，人々を捕える者たちよ。私を見よ！おお，神々を捕える者たちよ。 汝らは私を握らないであろう。汝らは私を掴まないであろう。汝らは汝らの望むことを， 私に対して行わないだろう。なぜなら私はその(汝の望みの)望みから出たからだ。私は「二 柱のマアト」のソカルの船によって，その支配から逃れたからだ。

私は［私の］口によって食べ，私の肛門によって排泄する。私を見よ！おお，存在す る者たちよ。私を崇扯せよ！狲，存在しない者たちよ。そこにいる存在する者たちが 私に崇帱を与えんことを。

第479章は,「網から逃れるための呪文」の一種である。死後の世界では, 鳥, もしくは魚となっ た故人を地上から天へと張り巡らされた網によって妨害する神が登場する。故人は網にかからない ために, 網やその他の部分の正しい名称を覚えなければならず, これはそのための魔除けの呪文で ある（Guglielmi 1976-92）。「存在する者」(nt(y)w), 「存在しない者」(iwt (y)w) については, こ の語の具体的な内容は不明であるが，それぞれ解釈冒頭部分の「人間を捕える者たち」(whrw rmt $)$ と「神々を捕える者たち」(whrw ntrw) に対応するものと考えられる。

呪文の所有者は，人間や神々を捕える「漁師」に対し，自分を妨げることはできないと明言し， その手段として「『柱のマアト』のソカルの船」への言及がなされている。これは,「二柱のマアト」 が担う死後の世界での役割と，ソカルと「二柱のマアト」との関係を示している。

「二柱のマアト」とソカルの関係を示す同様の表現は，呪文第660章（iii）にも確認される。

（4）42aの解釈は, 研究者ごとに異なる。フォークナーは「私は二柱の真実のソカルとしてその手中から逃れた」, バルゲは「私はソカルと二つのマアトに属する者によってその手から自身を引き離した」, カリエは「私がソカル, 『二 つのマアトに属する者』として自身を彼の支配から引き離したからだ」としている（Faulkner 1973-78, vol. 2, 123; Barguet 1986, 314; Carrier 2004, 1178-1179)。Skr n M3ctyの解釈に注目すると，フォークナーが「二つの真実のソ カル」とする一方で, バルゲ, カリエは「マアトに属する者」とし，またバルゲはM⿻゙丨

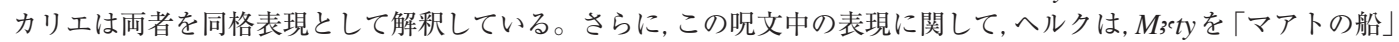
と訳している (Helck 1980, 1112)。これらの解釈の相違は, 文脈上の判断が困難であることに加えて, Msctyが「二 柱のマアト」,「マアトに属する者」「「マアトの船」と解釈できるだけでなく $k k r$ 「ソカル神」と「ソカルの船」 の二つの意味を持つ点に起因する。筆者は, M M t t n n Skrを漁師から逃れるための手段であると解釈し, また次の呪 文第 660 章の内容と併せて『柱のマアト」のソカルの船』と仮訳した。ここでは, Mstyと下界の神であるソカ ルの関係だけが明らかである。

( 5 ）続く $m$ crt.iとの同格表現と判断し, 補足した。

（６）「その」を意味する接尾代名詞. $s$ から，ここでは $m r t$ を指すと解釈した。

（７）正式な呪文の題目は「ijdtの網，ibt-t 3 , isswtの網，dsfの罠から逃れるための呪文。なぜなら私はそれを知っ ており，その名前を知っているからだ」( $r n$ prt [ $[m]$ ỉ $3 t$ i ibt-t $i b t-t 3, \underline{d} s f$ のいずれも網の名称と考えられる。(CT 6, 3) 
（事例 ii， iii）呪文第660章 $C T$ 6, 282a-f [B1Bo]
282 [a] hpr.n N pn nn hprt pt nn hprt t3
[b] hdn $p w n$ m-ht psw $n$ N pn
[c] iwt (y) shm wsw im.f
[d] nsw pw pr(i) fnd
[e] rdi.n (ii)M;ety e.sn $r \mathrm{~N} p n$
[f] hkr.t(i) hrw n skrkr.fm $\operatorname{Skr} n \underset{\text { (iii) } M ; c t y}{ }$

このN（死者）は天が生まれる前に，大地が生まれる前に生まれた。彼（このN）はこ の Nが調理した後のヘジェン植物, ウアウアがそれに対して力を持たないもの（植物）で ある。

彼は王, 鼻が前に出た者である。「二柱のマアト」は彼女らの腕をこのNに置いた。彼 女らが空腹であるとき，このセケルケルの日に，「二柱のマアト」のソカルの船の中で。

第660章は，B1Boのみに記述が残る長大な呪文である。まず，呪文の所有者は自身の起源が神々 よりも早いことを主張し，「二柱のマアト」から力を得る。この呪文には，マアトに関する語は 4 例 確認され，そのうち前半の 2 箇所が $M \rtimes t y の$ 事例にあたる。

翻訳の前半部分では, 棺の所有者は, 自身の創造が原初の時から始まり, 自身が魔物を寄せ付け ないへジェン植物であり, 王であると述べており, その文脈のなかで「二柱のマアト」が彼に腕を 置いている $($ 事例ii $)$ 。この「腕を置く」（rdic）は葬祭文書にしばしば見られる表現であり，主と して神々が故人に力を与えるという意味で用いられる。したがって，ここでは二柱のマアトが呪文 の所有者に力を与える存在であることがみてとれる。マアトは, 正義や真実を示す象徴として頻繁 に用いられるが，行為を伴う独立した女神として描写されることは少なく，このように神格化され たマアトが故人に対して力を与える事例は極めて稀である。しかしこの事例から，「二柱のマアト」 が死後の世界の危険から身を護る力を故人に与える女神とされていたことがうかがえる。

（８）skrkrは，意味不明な名詞である。カリエ，バルゲはそれぞれ異なる訳を当てているが（Barguet 1986, 408; Carrier 2004, 1502-1503)，いずれの解釈も根拠が不明瞭である。フォークナーは，後述のソカルとは無関係であ るとのみ指摘している（Faulkner 1973-78, vol. 2, 230)。

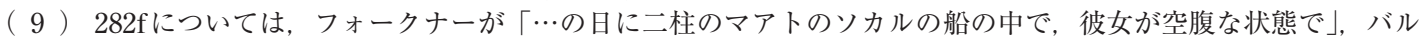
ゲが「二柱のマアトはその移動（?）の日に彼女らが空腹な状態で，二柱のマアトのソカルとして」，カリエが「彼 が二柱のマアトのソカルの船の中へ押し寄せるその日に, 空腹な状態で二柱のマアトが」としている（Faulkner 1973-78, vol. 2, 230; Barguet 1986, 408; Carrier 2004, 1502-1503)。いずれの解釈も hkr.t(i)を状態形とする点での 見解の一致が見られるものの, m Skr n M ctyの解釈が異なる。M のマアトのソカルの船のなかで」とする一方で, バルゲは「二柱のマアトのソカル」としている。この節の呪文の 内容は下界に関係するため, ここで登場する $S k r$ の語は下界を移動するソカルの船を指すと判断できる。また，Skr に前接する $m$ が場所を表す前置詞であると解釈し,ここでの $m$ S $k r n M r t y$ を「二柱のマアトのソカルの船のなかで」 と解釈すれば, 前節 $282 \mathrm{e}$ の Mrty との齟龉も生じない。

(10) 魔物の一種である（Leitz 2002, vol. 2, 244）。

（11）字義通り訳したが, 具体的な意味は確定できない。フォークナーは「調べる者」, バルゲが「不安な者」, カリ エは「怒った者を外に出す者」と訳しているが，論拠は不明である（Faulkner 1973-78, vol. 2, 230; Barguet 1986, 408; Carrier 2004, 1502-1503)。

（12）古王国時代の「ピラミッド・テキスト」にも同様の表現が見られる。例えば，呪文第 600 番では，カーを受け 継ぐため, 故王がアトゥム神にその腕を置く（力を与える）ことを求めている（Sethe 1910, 373）。 
続く事例（iii）では, 事例（i）と同様に「二柱のマアト」とソカルとの関係を示す表現が見られる。 神話上でのソカルの役割の一つは，太陽が夜に下界を旅するのを助け，朝に復活させることであっ た。ここでは，下界で故人を保護するソカルの船を司る者として「二柱のマアト」が表現されたと 考えられる。

呪文第 479 章と呪文第 660 章の M⿻tryの三つの事例は, 「二柱のマアト」の持つ二つの特徵を示す。 まず，呪文第479章の事例（i）と第660章の事例（iii）は，ソカル神と「二柱のマアト」との関係 性を示しているが，両者の結びつきは，古王国時代の「ピラミッド・テキスト」の呪文には見られず， 「コフィン・テキスト」が初出である（肥後 2015, 220-225）。また，第660章の事例（ii）は，故人 に力を与える独立した女神，「二柱のマアト」について言及している。下界のマアトは，現世での 善悪の基準や, 正義あるいは真実の象徵として認識されるのが一般的だが, ここでの「二柱のマアト」 は，下界で故人に力を与える神格とされている。

\title{
3. 独立した人格神としてのM;ety
}

\author{
（事例iv）呪文第149章 $C T 2,250 \mathrm{~b}-\mathrm{c}[\mathrm{S} 1 \mathrm{P}]$ \\ 250
[b] iw whm $r$-gs $\frac{\text { (iv) } M ; c t y}{(15)}$
[c] rdit shm.i $m$ hft.i

それ (私の叫び) は,私を私の敵に対して力強くする「二柱のマアト」の前で繰り返された。

第149章は, 変身の呪文と, 棺の所有者に力を与えるための呪文である。「コフィン・テキスト」 のなかで大きな比重を占める変身の呪文は，危険に溢れた来世において，故人が身を守るために利 用された。

（13）主語が省略された $s \underline{d m} . f$ 形となっており, 解釈が分かれている。バルゲとカリエが $w h m$ の後に一人称の接尾代 名詞.斺省略されていると解釈する一方で，フォークナーは，非人称の受動文として解釈している。ここで動詞に 注目すると,「繰り返す」を意味する動詞 $w h m$ は他動詞であるため, バルゲやカリエのように「私は繰り返す」と した場合, 目的語が欠如した文となる。したがってここではフォークナーの解釈にしたがい「それは繰り返される」

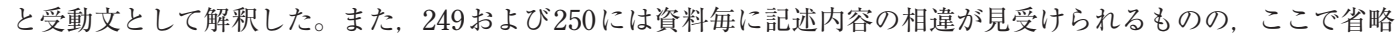
された「それ」は，249aの「私はあの敵のゆえに叫んだ」(iw.n.i hr hft pf) の内容を指すと考えられる (Faulkner 1973-78, vol. 1, 128; Barguet 1986, 437; Carrier 2004, 360-361; CT 2, 249-250)。

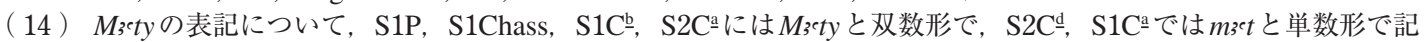

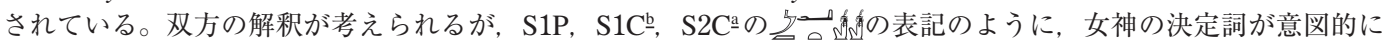

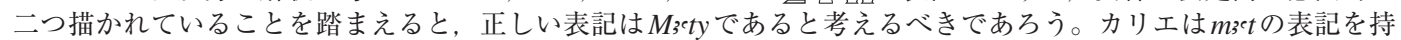
つS1Caを解釈の資料としながらも，この部分を双数形として解釈している (Carrier 2004, 360-361; CT 2, 250)。

（15）フォークナーは, ○のを「柱のマアト」を修飾する完了分詞, shmを「力」とし,「私に力を与えた (マアト)」(rdit shm.ỉ) としている (Faulkner 1973-78, vol. 1, 128)。しかし,「私に」と与格として解釈する場合, 接尾代名詞.iの

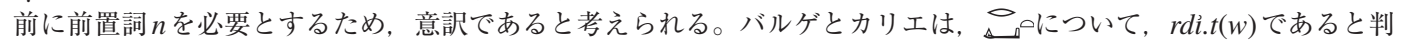
断し,「人」( $t w)$ を主語とした関倸形と解釈している (Barguet 1986, 437; Carrier 2004, 360-361)。その上で前者は「人 が私に対して力を与えた (二柱のマアト)」, 後者は「人が私に力を持つことを許可した (二柱のマアト)」としている。 しかし, 両者の解釈はともに, 関倸形の中に目的語が含まれているため, 文章として成立せず, 疑問が残る。筆者 は, rditを使役の機能を果たす動詞 $r d i$ の完了分詞, shm.i $\operatorname{sh}$ を 釈した。

（16）呪文の題目は「(人間の) 隼になること, 墓域で人をアク（3h) にすること, その者の敵に対して人に力を与 えること, 人がリネンの白いサンダルを履き, 服を身に着けて話すこと」(hpr m bik (rmt s s h h h s rdit shm s m hft (y). $f \underline{d} d s \underline{t} b(i w) m$ h $\underline{d} d t y i d m i s d(w) m n \underline{d})$ である（CT 2, 226-227）。

（17）変身の呪文については，吹田1995を参照。 
この呪文では, オシリスの前で発せられた故人の叫びが「二柱のマアト」の前で繰り返されている。 そして二柱のマアトには,「私の敵に対して力強くする」(rdit shm.i $m$ hft.i $)$ と説明されている。こ の点から, 故人に力を与える独立した神としての「二柱のマアト」の性格がうかがえる。

（事例 v）呪文第 416 章 $C T$ 5, 249a-250f [S2Cํㅡ]

249 [a] $r n k r s t$

[b] $\operatorname{pr}(i) \cdot n . i, h 3(i) \cdot n . i$

[c] hss(i).i hast.n.i

[d] irt.n.i ỉhm[st]

[e] wn.n.i sbiwy

[f] $\operatorname{pr}(i) . n . i \hat{h r} r[\stackrel{(20)}{w d}]$

(2i) (22)

$[\mathrm{g}] \quad[\check{s} s p][. n] . . . i \stackrel{I}{I} n w w-s w$

250 [a] che.n.i r pt m $\underline{\text { (v) } M \text { «cty }}$

[b] $\quad g m(i) . n . \grave{l}$ ist Re-İtm

[c] $\underline{d} d$.sn i⿱⺌ wi $\underline{d} d(w) m c t$

[d] $\operatorname{ptr}(w) n f r t$

[d] ptr(w) nfrt

[e] $\quad p r(i) h r r w \underline{d} n$ moc-hrw

[f] twt $\underline{d} d(w)$ iwt.f

(18） S2C-a, B2Boより補足した（CT 5, 249）。

(19) フォークナーは，249eを受身の $s \underline{d} m w . f$ 形としている（Faulkner 1973-78, vol. 2, 66）。

(20) B2Bo, B4Bo, M22Cより補足した $(C T 5,249)$ 。

(21) B2Bo，B4Boより補足した $(C T 5,249)$ 。

（22）ライツの辞書では一種の神格として説明されているが，詳細は不明である。また，B2Bo，B4Boに見られる

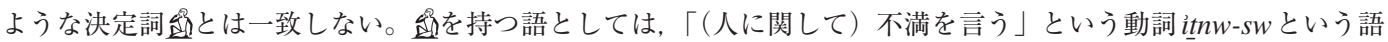
が挙げられるが，呪文の内容との関連性は低い（CT 5, 249; Leitz 2002: vol. 1 623; Hannig 2009, 129)。

（23）カリエのみ, che.n.i r ptを sdm.n.f形動詞文を名詞化した強調構文としている（Carrier 2004, 1028-1029）。

（24）250d-fに解釈の相違が見られる。フォークナーは「汝は善いものを見る。声正しき者の階段を上れ，なぜなら 汝こそは彼 (自身) が来るであろうと言った者だからだ」とし，バルゲは，「美しいものを見る者よ。勝利の階段 を進む者よ，汝は，『来るであろう者』と言う者だ」，カリエは「美しいものを見よ! 正当化の階段を登れ。（な ぜなら）汝は『来るであろう者』と告げる者だからだ」としている（Faulkner 1973-78, vol. 2, 66; Barguet 1986, 159; Carrier 2004, 1028-1029; CT 5, 249-250)。しかし，いずれの解釈も決定的ではなく，特に250fの意味が曖昧 である。これらの節の解釈について，筆者はまず, 250e の $p r(i) h r r w d に$ 注目したい。この表現と類似する記述が 同呪文中の $249 f$ に見られ，そこで「私は階段に出た」 $(p r(i) h r r w d)$ と述べられていることから，「私」が既に階段 を上っていることが明らかである。したがって，250e は命令文ではなく，「階段を登りし者」と完了の能動分詞と 解釈されるべきであり，その場合 $249 \mathrm{f}$ の内容との齟䶣も生じない。また, $250 \mathrm{~d}$ の ptr nfrtも同様に「美しいものを 見た者」と完了分詞として解釈ができ，さらに，その前節 $250 \mathrm{c} の d d . k m 3 c t$ に関しても接尾代名詞. $k$ を誤記と判断

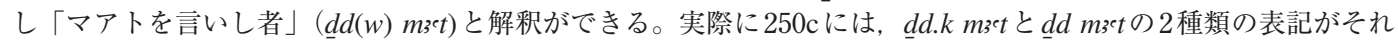
ぞれ2例ずつ見られる。このように解釈すれば,「ようこそ!」( 到 wi)に続いて「マアトを言いし者」,「善いものを 見つけし者」，「声正しき者の階段に出た者」と死者への敬称の羅列が続き，より整合性のある解釈となる。また， 250fに関しては，鸟を「言う者」のような能動分詞ではなく，「言われし者」 $(d d(w))$ と受動分詞，凡乃のを「彼 が来んことを」(iwt.f) と仮定法 $s d m . f$ 形の名詞化として解釈した。この呪文の中で故人は, ラー・アトゥムの船員 を発見し，「ようこそ」（ｉｗi） と迎え入れられる。この250fを船員らによる歓迎の発言として捉えるならば，筆者 の示した「汝こそは『彼 (死者) が来んことを』と言われし者である」という解釈は, 死者が船員たちのもとへ来 ることを歓迎される発言として，蓋然性が高いといえる。

( 25 ) B2Bo, B4Bo, M22Cより補足した $(C T 5,250)$ 。 
埋葬の呪文。

私は行って，やって来た。私は私が紡いだものを紡ぐ。私が作ったものは，イヘメセト の紐だ。私は二つの扉を開けた。私は階段の上を進んでいった。私はイチェヌウ・スウを取っ た。私は天に向かって「二柱のマアト」とともに立ち上がった。私はラー・アトゥムの船 員を見つけた。彼らは言う。「ようこそ! おお,マアトを言いし者, 善いものを見つけし者, 声正しき者の階段に出る者よ，汝こそは『彼が来んことを』と言われし者である。」

第416章は「埋葬の呪文」と題された呪文である。しかし，ここで描写されているのは, 埋葬に 直接関係する事柄ではなく埋葬後の死者の来世への旅の様相である。前半部分では，故人は二つの 屝を開け，階段を進んでいる。「二つの屝」( sb swy) は，おそらく死後の世界へつながる屝を指し， 階段は，天あるいはラーの船へとつながる階段を示すと考えられる。

後半部分では, 故人はラー・アトゥムの船員を発見し, そこで彼らから歓迎の言葉を受ける。お そらく自身の正当性を認められた故人は,「ラー・アトゥムの船」すなわち太陽（神）の乗船を許 されるのであろう。

故人が「二柱のマアト」(M⿻ty) とともに「立ち上がる」ことから，ここでの「二柱のマアト」も， 故人とともに行動する神だと推測される。なお， $250 \mathrm{c} に$ 表記された「マアトを言いし者」 $(d d d(w)$ $m ; c t ）$ のアトは，明らかにマアト女神とは別の抽象概念である。

第660章の事例（ii）に続いて，第149章（iv）と呪文第416章（v）のM`tyの表現にも，「二柱の マアト」の独立した人格神としての側面が見られる。とりわけ第 149 章（iv）には,「二柱のマアト」 が故人に力を与える神であることが明確に示される。

\section{4. ラーとの関係}

（事例 vi）呪文第 682 章 $C T$ 6,312n-312p [B1Bo]

\section{2 [n] N pn mn m pt smn m pt \\ [o] $m s b b$ wr $m$ ser $R^{\circ} n$ (vi) Mscty. $f$ \\ [p] $\quad m$ sbb nhh hrw pw $n$ ḥts rnpt}

このNは天で永続し，天で安定した。

大いなる者に達する者として, ラーを彼の「二柱のマアト」へと登らせる者として, 年 の終わりのこの日に永遠に達する者として。

神々の世界で故人の正当性を示す呪文である第 682 章については, 資料である棺が B1Boの一点 しか発見されて扔らず，また欠損部分の多さや，呪文の所有者を示す接尾代名詞の. $f$ と.s が混在し

（26）動詞刃ل只 $s b(i)$ の解釈によって訳が異なる。フォークナーは他動詞「送る」と捉え， $w r$ を目的語とする分詞 として訳し，一方でバルゲとカリエは自動詞「行く」とし， sbb wr と ser Reをそれぞれ名詞化された $s d m . f$ 形とし ている (Faulkner 1973-78, vol. 2, 248; Barguet 1986, 452; Carrier 2004, 1552-1553; CT 6, 312)。「大いなる者」(wr) はラーやオシリスをはじめとする様々な神々の別称として用いられるため, ここでの特定は難しく, 解釈の判断も 困難である。筆者は, $s b b$ を他動詞「達する」の未完了分詞であるとし,「大いなる者に達する者」と訳した。続く $s e r$ と $b b$ に対しても同様の解釈をとった。 
ていることから， 正確な解釈と内容の理解が困難である（Faulkner 1973-78, vol. 2, 249）。この呪文 の大まかな内容を示すと, 前半部分では, 故人の出自に関する神話的な説明がなされ, その後, イ シスとネフティスによる問答がなされる。後半部分では, おそらく神官が語り手となり, 故人が様々 な力を備え, 正当性を持つことを主張する。その後, 故人の肉体がミイラとされ, 力を得ることで 天に昇り，そこに留まるというものである。

$M \rightsquigarrow t y の$ 表現が見られるのは, この呪文の末尾(312o)である。ここに見られる動詞䏸 $(s e r)$ は, 「登 らせる」や「近づける」を意味する使役動詞であり,ここでは, Rcを目的語, M⿻tyを与格として「ラー を彼の『二柱のマアト』へと登らせる者」という表現に用いられている。この点から,ここでの「二 柱のマアト」は, 太陽神ラーの到達点である天上に存在することがうかがえる。また, Matyの後には, 神名に通常付加されることのない接尾代名詞. fが付加されており, この点からもMrctyを女神ではな く, 天にある何らかの場所の名称として示されていると考えるのが自然である。同様の表現は, 続 く事例（vii）にも見受けられた。

（事例 vii）呪文第693 章 $C T$ 6, 326o-326p [B15C]

$326 \quad[\mathrm{o}] \quad w n \cdots \cdot k w n \cdots \cdot k n n(?) \cdots[n m i] \cdot k$ hrt

[p] ph.n Re (vii)M;cty

…汝が天 [を横切る］のは, ラーが「二柱のマアト」に達したときなのである。

第 693 章は, B15C 以外に現存する資料がなく, 欠損も多いものの, 簡潔な内容であり, 大意をつ かむことができる。その内容は，ラー・アトゥムやラー，トトなどの神々が，棺の所有者を祝福し， 死者が力を持つことを望むというものである。Mstyの表現を含む箇所は, ラーによる二度目の祝 福の後に見られる。

第 682 章（vi）と同様に,「達する」を意味する動詞 $p h$ からら, ここでの M`ctyもラーの到達点を指 していると判断すべきであろう。「汝」は死者を指しており, ラーがM゙tyへと達した時に, 死者が 天を船で横切ることが可能となることが読み取れる。

呪文第 682 章（vi）と併せて考えると，おそらくこのMrtyは女神ではなく，天にある場所であり， 太陽の到達点であると考えられる。マアトと太陽神ラーの関係は, マアトが「ラーの娘」 ( $s 3 t R c)$ として表現されるように，通常は父子関係で示されるが，第682章（vi）と第693章（vii）に示さ れた到達点としてのM“tyについては, これまで触れられていない。この側面は, 従来のマアトと 太陽神との関係に新たな視点をもたらし得るものといえる。

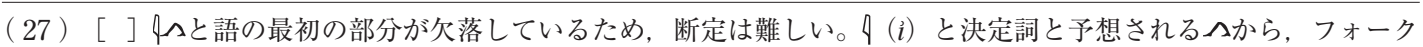

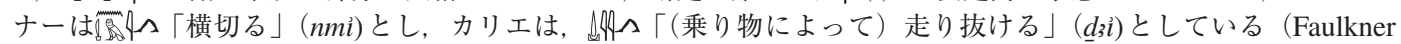
1973-78, vol. 2, 258-259; Carrier 2004, 1584-1585)。筆者はこの呪文がラーの船の航行に言及する内容であること を踏まえnmiと推測した。

（28）326oと326pの翻訳にあたって，フォークナーは326oを主文，326pを従属文とし，バルゲ，カリエはそれ ぞれを主文としている（Faulkner 1973-78, vol. 2, 258-259; Barguet 1986, 154; Carrier 2004, 1584-1585)。筆者は

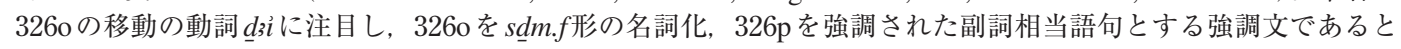
解釈した。 


\section{5.「ニ柱のマアト」の祭 (hb M;ety)}

（事例 viii）呪文第659章 CT 6 280a d [P. Gard.2]

[a] $\quad r n$ smi-t3 $^{3}$

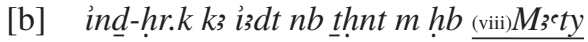

[c] $\quad h 3(i) . i r w i 3 . k$

[d] gwз $r$ rdw mi Hmn ihm(w) wrd

着岸することの呪文。

万歳！おお, 東方の雄牛, 「二柱のマアト」の祭におけるファイアンスの主よ。私は ヘメン, 疲れを知らない者のように階段にきつく結びつけられた汝の船へと下る。

「着岸するための呪文」である第659章は, 死者がラーの船の一員になるための呪文であり, 死 者がその船へと向かう様子を描写したものである。この呪文は, 不明な表現を多く含み, この「二 柱のマアト」が何を表しているかについても不明瞭である。280cの.kは太陽神ラーを指し，280b の内容はラーに向けての呼びかけだと考えられる。ラーは「『二柱のマアト』の祭におけるファイ アンスの主」として表現されているが，ラーがこのような形容辞によって表現される事例は少なく， 「『二柱のマアト』の祭」(hb Mrcty) は他に例を見ないマアトの使用例である。また，「マアトの祭」 の細部に触れた研究は, 未だなされていない。女神としてのマアトの崇拝が始まり, 神殿が造営さ れるのは一般に新王国時代以降だとされているが，この呪文は，「二柱のマアトの祭」と呼ばれる 儀礼が中王国時代に存在したことを示している。理解の困難な表現が数多くあるとはいえ，この事 例は中王国時代において女神のマアトが崇帱されていた可能性を示す興味深い事例といえる。

\section{IV.おわりに}

本稿では,「コフィン・テキスト」に表現された8例の「二柱のマアト」の記述を含む呪文に注目 し，これまで注目されていなかったマアトの一側面を明らかにした。

III. 2 の事例は, 「二柱のマアト」と下界の神であるソカルとの関係を示す。両者の関係は, 古王 国時代の「ピラミッド・テキスト」には認められず，マアトの概念が中王国時代には下界において 重要な役割を担うようになっていたことがうかがえる。次に，III. 3 で取り扱った二つの呪文から， 二柱の独立した女神としてのM־tyの性格がみてとれる。特に，第660章と第149章では，死者に対 して力を与える「二柱のマアト」の性格が示されていた。この性格は,「二柱のマアト」が独立し た神格として認識されていたことを示しており, 正義や真実, 秩序といった抽象概念とは明らかに 異なる側面である。III. 4 の事例は，太陽神ラーの到達点としてのMrtyの側面を示す。これは，太

（29） 280bの nb thnt $m h b$ M $; t y$ の部分について，その他の考えられる解釈は， $m$ 以下を副詞句とする副詞文の解釈

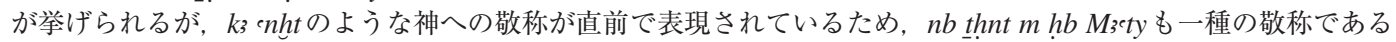
と解釈すべきであろう。

（30）古王国時代，中王国時代にマアトの神殿がなかったことも指摘されている (Helck 1980, 1114)。 
陽神ラーとマアトの関係を理解するうえで重要な, マアトの新たな性格をうかがわせるものである。

マアトの特殊な形態として「コフィン・テキスト」に見られる「二柱のマアト」(Mrty) は, 後の「死 者の書」の審判の場面における「二柱のマアトの間」に見られるように，古代エジプト人の思い描 くマアトの概念の本質に関わるものといえる。しかし, 二柱の女神として現れるマアトの研究はこ れまで十分になされていない。「コフィン・テキスト」の「二柱のマアト」はこれまで論じられなかっ たマアトの側面を理解するうえで貴重な事例である。依然としてその存在が確認されるのみに留ま る「二柱のマアト」への注目は, マアト研究の進展に重要な意味を持つものであり, 今後の研究に よる更なる解明が望まれる。

\section{謝辞}

本稿を執筆するにあたり, 関西大学文学研究科の吹田浩教授, カイロ大学考古学部のサラーハ・エル・ホーリ教授 に多大なるご教示を賜りました。なお，本研究は，文部科学省私立大学戦略的研究基盤形成支援事業（平成 25 年度〜 平成 29 年度, 事業番号 S1311041）の研究成果の一部です。

\section{略号一覧}

CT : $\quad$ Buck, A. de 1935-61: The Egyptian Coffin Texts, 7 vols., Chicago.

CT 2: $\quad$ Buck, A. de 1938: The Egyptian Coffin Texts, vol. 2, Chicago.

CT 5 : $\quad$ Buck, A. de 1954: The Egyptian Coffin Texts, vol. 5, Chicago.

CT 6: Buck, A. de 1956: The Egyptian Coffin Texts, vol. 6, Chicago.

CT 7 : Buck, A. de 1961: The Egyptian Coffin Texts, vol. 7, Chicago.

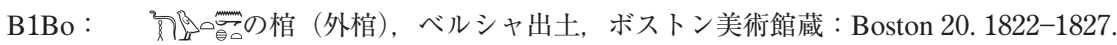

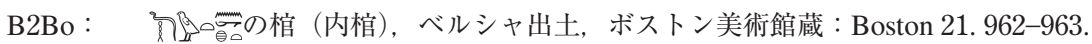

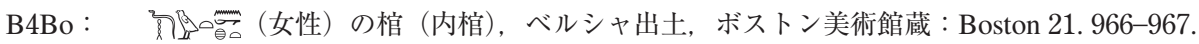

B1C： דの棺, ベルシャ出土, カイロ博物館蔵 : Cairo 28083 ,

B3L： 点の棺 (内棺), ベルシャ出土, 大英博物館蔵：B. M. 30842.

M22C：所有者不明の木板, メイル出土, カイロ博物館蔵：Cairo JE42828.

P. Gard.2：所有者不明のパピルス, 出土地不明, 大英博物館蔵（詳細不明）.

S1C : - 一棺 (内棺), アシュート出土, カイロ博物館蔵 : Cairo 28118.

S1C는 一棺 (内棺), アシュート出土, カイロ博物館蔵 : Cairo 28118.

S1Chass： 而们棺の蓋部分, アシュート出土, 所在地不明.

S2C： 一棺 (外棺), アシュート出土, カイロ博物館蔵 : Cairo 28119.

$\mathrm{S}^{\mathrm{C}} \mathrm{C}^{\mathrm{b}}$ - 一棺 (外棺), アシュート出土, カイロ博物館蔵 : Cairo 28119.

S1P：晋 の棺 (外棺), アシュート出土, ルーブル美術館蔵（現在は所在地不明）.

\section{参照文献}

Altenmüller, B. 1975: Synkretismus in den Sargtexten, Wiesbaden.

Assmann, J. 1990: Ma'at: Gerechtigkeit und Unsterblichkeit im Alten Ägypten, München.

Barguet, P. 1986: Les textes des sarcophages égyptiens du Moyen Empire, Paris.

Bleeker, C. J. 1929: De betekenis van de Egyptische godin Ma-a-t, Leiden.

Carrier, C. 2004: Textes des sarcophages du Moyen Empire Égyptien, 3 vols., Orne.

Faulkner, R. O. 1973-78: The Ancient Egyptian Coffin Texts, 3 vols., Warminster. 
Frankfort, H. 1948: Kingship and the Gods: A Study of Ancient Near Eastern Religion as the Integration of Society and Nature, Chicago.

Guglielmi, W. 1982:“Netz,” in W. Helck and E. Otto (eds.) 1982: Lexikon der Ägyptologie vol. 3, Wiesbaden, $464-465$.

Hannig, R. 2009: Großes Handwörterbuch Ägyptisch-Deutsch (2800-950 v. Chr.): Die Sprache der Pharaonen, Marburger Edition, Mainz am Rhein.

Helck, W. 1980: "Maat,” in W. Helck and E. Otto (eds.) 1980: Lexikon der Ägyptologie vol. 3, Wiesbaden, 1110-1119.

Hornung, H. 2005: Der Eine und die Vielen: Altägyptische Göttervorstellungen, $6^{\text {th }}$ ed., Darmstadt.

Karenga, M. 2004: Maat, the Moral Ideal in Ancient Egypt: A Study in Classical African Ethics, New York.

Leitz, C. (ed.) 2002: Lexikon der ägyptischen Götter und Götterbezeichnungen, 8 vols., Leuven.

Lichtheim, M. 1992: Maat in Egyptian Autobiographies and Related Studies, Göttingen.

Morenz, S. 1973: Egyptian Religion, London, 1974.

Moret, A. 1940: "La doctrine de Maât," Revue d'égyptologie 4, 1-14.

Sethe, K. 1910: Die altägyptischen Pyramidentexte: Nach den Papierabdrücken und Photographien des Berliner Museums, vol. 2, Leipzig.

Teeter, E. 1997: The Presentation of Maat: Ritual and Legitimacy in Ancient Egypt, Chicago.

Tobin, V. A. 1989: Theological Principles of Egyptian Religion, New York.

Wiedemann, A. 1887: “Maa: Déesse de la vérite et son role dans le panthéon égyptien,” Annales du Musée Guimet 10, 561-573.

Wilson, J. A. 1954: “Authority and Law in Ancient Egypt," Supplement to the Journal of American Oriental Society, 17, 1-7.

Willems, H. (ed.) 1996: The World of the Coffin Texts: Proceedings of the Symposium Held on the Occasion of the 100't Birthday of Adriaan de Buck, Leiden, 17-19 December 1992, Leiden.

吹田浩 1995 :「コフィン・テクスト第275章」『関西大学文学論集』44, 311-327.

肥後時尚 2015 ：「古代エジプト古王国時代のマアトの一側面：ピラミッド・テキスト第260番から」The Journal of Center for the Global Study of Cultural Heritage and Culture（関西大学国際文化財・文化研究センター紀要）2, $215-228$. 